\title{
Afiliasi Partai Aceh Ke Partai Nasional (Studi Kasus: Keikutsertaan Kader Partai Aceh Dalam Partai Nasional Pada Pemilu Legislatif DPR RI 2019)
}

\author{
Rahmad Saputra ${ }^{1}$, Muradi ${ }^{2}$ Leo Agustino ${ }^{3}$ \\ ${ }^{1}$ Program Studi Ilmu Politik, Universitas Padjajaran, Indonesia. \\ ${ }^{2}$ Program Studi Ilmu Politik, Universitas Padjajaran, Indonesia. \\ ${ }^{3}$ Program Studi Ilmu Politik, Universitas Padjajaran, Indonesia.
}

\section{ARTICLE INFORMATION}

Received: February 17, 2020

Revised: February 24, 2020

Accepted: April 19, 2020

Available online: April 30, 2020

\section{KEYWORDS}

Affiliations, National Parties, Local Political Parties, Aceh Party

\section{CORRESPONDENCE}

Phone: +62

E-mail: rahmad.bpersada@gmail.com

\section{A B S T R A C T}

\begin{abstract}
The purpose of this study is to analyze the relationship between local parties and national parties, to analyze the purposes of the Aceh Party's relationship with national parties in the 2019 legislative elections, and to analyze the tactics used by Aceh in its alliance with national parties in the 2019 legislative elections. The reasearch uses a qualitative method with an explanatory approach. The data collection techniques to be used in this research consisted of semi-structured interviews, observations and documentation studies to assess the intent of the political affiliation of Aceh Party cadres to national parties. This reasearch has shown that the Aceh Party continues to aim to struggle continuously for the rights of Aceh, in particular the question of special autonomy that has not yet been achieved. Then, as a local party that won the General Election in Aceh since 2009, the Aceh Party continued its efforts to retain seat acquisition and extend the party's interests, in particular, by putting its cadres in the national party at national level
\end{abstract}

\section{PENDAHULUAN}

Momentum 15 Agustus 2005 merupakan sebuah momentum bersejarah bagi masyarakat Aceh dimana pada tanggal tersebut tercapainya kesepakatan damai Memorandum of Unterstanding (MoU) antara Pemerintah Republik Indonesia dan Gerakan Aceh Merdeka (GAM) di Helsinki, Finlandia, yang difasilitasi oleh Martti Ahtisaari dari Lembaga Crisis Management Initiative (CMI). Penandatanganan nota kesepahaman antara Gerakan Aceh Mardeka (GAM) dan Pemerintah Republik Indonesia melahirkan beberapa konsesus tentang keistimewaan yang akan dimiliki oleh Aceh, salah satu konsesus tersebut adalah kebebasan masyarakat Aceh dalam mendirikan partai politik lokal sebagai saluran aspirasi politik eks kombatan GAM dan seluruh masyarakat Aceh.

Rumusan MoU tentang penyelenggaraan Pemerintah di Aceh terkait dengan partisipasi politik, dijelaskan bahwa sesegera mungkin, tetapi tidak lebih dari satu tahun sejak penandatanganan nota kesepahaman ini, Pemerintah Republik Indonesia diharuskan menyepakati dan akan menfasilitasi pembentukan partai-partai politik lokal berbasis di Aceh yang memenuhi persyaratan nasional.

Kehadiran partai politik lokal diharapkan kemudian menjadi wujud pelaksanaan desentralisasi dan otonomi daerah secara nyata dan riil serta sesuai dengan kebutuhan dan faktorfaktor nyata dari masyarakat Aceh untuk membentuk partai politik lokal. Hal ini sesuai dengan perintah MoU Helsinki dan kemudian tertuang dalam Undang-Undang Nomor 11 Tahun 2006 tentang Pemerintahan Aceh pada pada Bab XI tentang Partai Politik Lokal.

Hasil pemilu di Aceh pada saat itu, Partai lokal mampu mendapat dukungan dengan perolehan suara yang sangat dominan dari rakyat Aceh, hal ini dapat dilihat dari peroleh suara Partai Aceh di Dewan Perwakilan Rakyat Aceh (DPR Aceh), dari 69 kursi yang ada, PA memperoleh Sebanyak 33 Kursi (47\%) ditambah Partai Daulat Aceh 1 Kursi (1.4\%) Kemenangan partai lokal pada pemilu 2009 di Aceh tidak hanya pada tingkat provinsi, tetapi juga diikuti oleh kabupaten dan kota. (Keputusan Komisi Independen Pemilihan Pemilihan Aceh, Nomor 8 Tahun 2011).

Dukungan dominan masyarakat Aceh terhadap politik lokal seiring berjalannya waktu mulai menurun. Fenomena ini tidak hanya terjadi ditingkat Provinsi, tetapi juga terjadi di tingkat kabupaten dan kota di Aceh. hal ini dapat dilihat dari Pemilu legislatif pada 08 April tahun 2014 dimana perolehan suara partai lokal menurun secara drastis dibandingkan dengan tahun 2009. dari 81 kursi yang tersedia di DPR Aceh, PA hanya mampu memperoleh 29 kursi (36 \%), Partai Daulat Aceh 1 (1.2 \%) Kursi dan Partai Nasional Aceh 3 Kursi (3.7 \%) (Merdeka.com, 2019).

Menurut Aryos Nivada, Pengamat Politik dan Keamanan Aceh menjelaskan setidaknya ada dua hal yang mempengaruhinya. Pertama, munculnya perbedaan di antara elit Partai Aceh yang berujung pada perpecahan. Hal ini dapat 
dilihat dari munculnya Partai Nasional Aceh (PNA) yang merupakan barisan sakit hati pasca tidak dicalonkanya lagi Irwandi Yusuf Pilkada 2012, Kedua, kurangnya prestasi dan inovasi dari kader-kader Partai Aceh yang sedang menjabat saat itu, baik dikalangan legislatif maupun eksekutif. Kemudian masuknya Partai Aceh dalam perangkap partai nasional, hal tersebut disinyalir akibat afiliasi Partai Aceh dengan partai nasional di mana Ketua Umum Partai Aceh Muzakir Manaf yang juga menjadi Ketua Dewan Pembina di Partai Gerindra Aceh, berbeda halnya dengan Partai Gerindra di mana mereka sangat diuntungkan dengan koalisi tersebut (Serambi Indonesia, 2019).

Dalam sejarah kontestasi Pemilihan Legislatif di Aceh sejak Partai Gerindra berdiri tahun 2008, tidak pernah kader Partai Gerindra Aceh memenangkan kursi di DPR RI. Bahkan di tingkat lokal Aceh, Gerindra sama sekali belum mendapatkan tempat dihati masyarakat Aceh. Namun kondisi dan dinamika politik berubah pasca afiliasi politik antara Partai Aceh dan Partai Gerindra Aceh, partai besutan Prabowo Subianto berhasil mendapatkan kursi untuk DPR RI di dua dapil Aceh yang tersedia dan beberapa kursi di DPR Aceh dan DPRK seluruh Aceh. Keuntungan itulah yang yang didapatkan Partai Gerindra hasil afiliasi dengan Partai Aceh.

Munculnya nama Muzakir Manaf sebagai Ketua Dewan Pembina Partai Gerindra Aceh pada tahun 2014 mempertegas bentuk koalisi antara Partai Aceh dan Partai Gerindra pada Pemilu 2014. Hal ini dapat dilihat dari majunya beberapa kader Partai Aceh untuk DPR RI melalui kendaraan politik Partai Gerindra, yaitu Fadhullah dari Dapil I Aceh dan Tgk Khaidir dari Dapil II Aceh, keduanya kemudian terpilih menjadi anggota DPR RI Fraksi Gerindra mewakili Aceh.

Partai Aceh sebagai partai yang mendominasi pentas politik di Aceh menyadari bahwa pentingnya keberadaan kader tidak hanya pada satu partai saja seperti selama ini, akan tetapi kaderkader atau elit-elit Partai Aceh harus mampu mewarnai di semua partai politik. Hal ini dapat dilihat jelas dimana banyak kaderkader Partai Aceh mencalonkan diri menjadi anggota DPR RI di pemilu legislatif 2019 melalui kendaraan partai nasional yang ada di Aceh.

Diantara elit Partai Aceh yang mencalonkan diri ke DPR RI melalui kendaraan partai nasional antara lain, Tgk Muharuddin dari Partai NasDem, Kautsar melalui Partai Demokrat, Ermiadi melalui Partai Amanat Nasional, Azhari Cage melalui Partai Bulan Bintang, Effendi melalui Partai NasDem, Komaruddin melalui Partai Solidaritas Indonesia. Tidak hanya Partai Aceh yang berafiliasi, tetapi partai lokal lain seperti Partai Nasional Aceh (PNA) juga berafiliasi dengan partai nasional, sebut saja Sayuti Abubakar dari PNA yang maju ke DPR RI melalui kendaraan Partai Kebangkitan Bangsa, Yazid melalui PSI, dan beberapa kader partai lokal lainnya yang merangkap dua keanggotaan partai.

Di samping itu, keberadaan Muzakir Manaf sebagai Ketua Dewan Pembina Partai Gerindra yang juga Ketua Partai Aceh tidak pernah mengeluarkan ultimatum tentang mewajibkan kader-kader Partai Aceh baik yang saat ini menjabat anggota DPR Aceh maupun tidak agar mencalonkan diri melalui Partai Gerindra, sehingga memberi sinyal bahwa menempatkan kaderkader terbaik mereka di semua partai politik nasional menjadi salah satu strategi Partai Aceh pada Pemilu 2019.

Berdasarkan uraian di atas kemudian menjadi bahan kajian dalam penelitian peneliti untuk melihat Menganalisis hubungan yang terjadi antara partai lokal dan partai nasional?.
Dalam konteks politik, afiliasi politik berasal dari kata affiliate atau affiliation. Marbun (Doni Hendrik, 2010) merumuskan afiliasi politik sebagai kerjasama atau keterlibatan para anggota baik individu atau kelompok yang terlibat dalam kegiatan politik. Sementara Amir Taat Nasution (Novita Gustian Ningsih, 2018) menyebut jika afiliasi politik merupakan penggabungan dua kelompok yang memiliki anggota yang berbeda yang kemudian menggabungkan diri menjadi satu.M. Surya Endra (Novita Gustian Ningsih, 2018) menjelaskan bahwa afiliasi politik memiliki dua bagian, Pertama Afiliasi Politik defensive, sifat dari afiliasi politik ini terkesan pragmatis karena proses afiliasi politik ini hanya berlangsung sesaat sampai kedua kepentingan yang berafiliasi saling terjaga. Biasanya afiliasi politik bagian dari upaya membela diri akibat tekanan dari luar. Kedua Afiliasi Politik Offensive, sifat dari afiliasi politik ini adalah menyerang kubu lawan dengan melibatkan banyak kelompok untuk kepentingan dan keuntungan politik yang lebih besar.

Dalam sebuah negara demokrasi, partai politik memiliki peranan penting untuk kemajuan suatu bangsa. Partai politik melalui kader-kadernya bertarung dalam pemilu yang kemudian mengisi jabatan-jabatan publik untuk menentukan kebijakan. Hal ini sesuai dengan apa yang disampaikan dalam UndangUndang Nomor 2 Tahun 2011 Tentang Partai Politik, pada Pasal 1 ayat 1 dijelaskan bahwa, partai politik adalah organisasi yang bersifat nasional dan dibentuk oleh sekelompok warga negara Indonesia secara sukarela atas dasar kesamaan kehendak dan cita-cita untuk memperjuangkan dan membela kepentingan politik anggota, masyarakat, bangsa dan negara, serta memelihara keutuhan Negara Kesatuan Republik Indonesia sesuai dengan amanat Pancasila dan Undang-Undang Dasar Negara Republik Indonesia Tahun 1945.

Sejarah keberadaan partai lokal di Indonesia bukanlah barang baru, partai lokal sudah ada sejak tahun 1955 saat pemilu pertama kali diselenggarakan. Namun seiring berjalan waktu dan dinamika politik yang terus berubah, partai politik lokal berangsur hilang terutama karena adanya kebijakan pemerintah yang membatasi ruang gerak partai lokal pada masa Orde Baru, dan adanya penyederhanaan sistem kepartaian yang hanya mengakui keberadaan tiga partai.

Menurut Jafar (2009) partai politiklokal merupakan organisasi yang masyarakatnya memiliki kepentingan yang lebih kurang sama dan bersepakat untuk memperjuangkan kepentingan kelompoknya secara damai ditingkat lokal. Sedangkan Syamsuddin Haris menjelaskan Partai politik lokal disebut sebagai partai politik lokal memiliki dua definisi yaitu partai-partai nasional yang tidak memenuhi syarat UU untuk mengikuti pemilu nasional maka partai tersebut bersifat lokal dan jika partai lokal tersebut mendapat dukungan luas di publik maka 'statusnya' naik menjadi partai nasional (Nugraha, 2012).

Dalam Peraturan Pemerintah Nomor 20 Tahun 2007 Tentang Partai Politik Lokal dijelaskan bahwa yang dimaksud dengan partai politik lokal adalah organisasi politik yang dibentuk oleh sekelompok warga negara Indonesia yang berdomisili di Aceh secara sukarela atas dasar persamaan kehendak dan cita-cita yang memperjuangkan kepentingan anggota, masyarakat, bangsa, dan negara melalui pemilihan anggota DPRA/DPRK, Gubernur/Wakil Gubernur, Bupati/Wakil Bupati, dan Walikota/Wakil Walikota.

KemudianParty switchingatau peralihan partai bukanlah hal baru dalam studi politik. Peralihan partai secara umum menjelaskan pergantian partai yang dilakukan oleh anggota 
legislatif yangterjadi menjelang pemilu ataupun pengambilan dukungan politik. Sebagai contoh kasus di Amerika Serikat pada tahun 2009, Arlen Specter yang semula sebagai legislator dari Partai Republik loncat ke Partai Demokrat untuk mempengaruhi dukungan senat di parlemen guna mendukung Partai Demokrat. Tak hanya di Amerika Serikat, fenomena party switchingjuga terjadi beberapa dekade sebelumnyaseperti di Brazil dengan 39\% legislatornya melakukan party switching pada rentang waktu satu periode (1991-1994), di Italia dengan 33,7\% (1992-1994), Spanyol dengan 12\% (1986-1989), dan di parlemen Eropa dengan 16\% (1989-1994) (Radean, M : 2013 dalam Heller \& Mershon 2008)

Party switching yang dilakukan oleh para legislator dipengaruhi oleh banyak faktorseperti pertimbangan ideologis, ambisi politik, akses politik, dan pertimbangan saat pemilihan umum. Namun dalam studi lainnya, faktor-faktor tersebut tidak dapat digeneralisasi karena peralihan partai juga dapat disebabkan oleh posisi legislator apakah dia seorang petahana dan merupakan anggota legislatif yang memiliki peran yang besar atau peralihan partai karena partai yang dipilih selanjutnya memiliki dukungan sumber daya finansial, ataubiaya transaksi politik (Radean, M, 2013). Tapi dalam peralihan partai akan terjadi jika para kandidat ataupun legislator yang ingin pindah partai diterima di partai barunya. Hal ini menjadi penting karena fenomena pergantian partai ini sangat tergantung dari kualitas atau figur para legislator yang dinilai oleh partai barunya apakah memiliki nilai tawar yang menguntungkan, sesuai dengan garis ideology partai, atau memberikan manfaat lainnya.

\section{METODE}

Penelitian ini akan dilakukan dengan menggunakan metode kualitatif dengan pendekatan deskriptif. Cresswell (2012) menjelaskan bahwa penelitian kualitatif merupakan proses penyelidikan permasalahan yang mengeksplorasi masalah sosial atau manusia. Kemudian Moleong (2010), berpendapat bahwametode penelitian kualitatif adalah penelitian yang bermaksud untuk memenuhi dan menjawab fenomena tentang apa yang dialami oleh subyek penelitian, misalnya prilaku, persepsi, motivasi, tindakan, dan lain-lain, secara holistik dan dengan cara deskripsi dalam bentuk kata-kata dan bahasa, pada suatu konteks khusus yang berdasarkan alamiah dan dengan memanfaatkan berbagai metode. Untuk Untuk kebutuhan data maka informan yang diwawancarai berasal dari unsur elit Partai Aceh seperti Ketua Umum Partai Aceh, para fungsionaris Partai Aceh, para elit Partai Aceh yang mencalonkan diri ke DPR RI melalui partai nasioanal, dan para akademisi di Aceh. Lokasi penelitian di Provinsi Aceh bertempat di kantor Partai Aceh (PA)dan tempat lainnya yang disesuaikan dengan kondisi dan kesepakatan antara peneliti dan informan nantinya.

Adapun alasan digunakannya metode penelitian deskriptif kualitatif adalah untuk menjelaskan hasil dari wawancara terhadap informan penelitian secara menyeluruh. Tujuannya untuk menjelaskan secara keseluruhan hasil dari wawancara sebagai sumber data dari penelitian kualitatif. Dengan menggunakan metode penelitian kualitatif, diharapkan dapat mengungkapkan maksud dari fenomena migrasinya elite partai lokal ke partai nasional dalam konstetasi politik legislatif 2019 dan tujuan afiliasi partai lokal Aceh yang belum tersampaikan ke publik.
Teknik pengumpulan data yang akan dilakukan pada penelitian ini terdiri dari wawancara semi terstruktur, observasi, dan studi dokumentasi. Setelah menentukan kriteria informan, kemudian peneliti menggunakan teknik pengumpulan data melalui wawancara semi terstruktur. Wawancara ini menggunakan pedoman wawancara sebagai acuan, namun dalam pelaksanaannya penulis boleh mengembangkannya dan melakukan improvisasi, selama tidak melebar dari fokus dan ruang lingkup penelitian yang telah ditentukan. Wawancara difokuskan untuk memperoleh informasi terkait sejarah lahirnya partai politik lokal dan dinamika di tiga pemilu legislatif serta peranan para elit partai dalam menyikapi kepindahan para kadernya dan hubungan antara Aceh - Jakarta pasca damai.

\section{HASIL DAN PEMBAHASAN \\ Awal Mula Pembentukan Partai Lokal di Aceh}

Pendirian partai politik lokal telah muncul sejak tahun 1955 yang merupakan pemilu pertama di Indonesia. Herbert Feith (1999) yang meneliti fenomena politik pada waktu itu membagi empat jenis partai politik yang ikut dalam Pemilu 1955 yaitu partai besar yang terdiri dari PNI, Masyumi, NU dan PKI, partai menengah (PSII, Parkindo, Partai Katolik, PSI, Perti, dan IPKI), partai kecil dengan basis massa nasional (PRN, Partai Buruh, GPPS, Partai Murba, Permai, Acoma, Baperki), dan kelompok partai kecil lainnya yang bercakupan secara daerah. Kelompokkelompok kecil inilah dalam penelitian Feith dapat dikategorikan sebagai partai lokal karena bersifat kedaerahan seperti yang ada di Jawa Barat, (Partai Rakyat Desa (PRD), Partai Republik Indonesia Merdeka (PRIM), Gerakan Pilihan Sunda), di Yogyakarta dengan Gerinda, di Kalimantan Barat (Partai Persatuan Daya), Madura (Angkatan Kesatuan Umat Islam), dan Nusa Tenggara Barat (Persatuan Indonesia Raya) (Nugraha, 2012).

Tapi hampir seluruh partai politik lokal yang berkompetisi pada Pemilu tahun 1955 mayoritas mengalami kegagalan di daerahnya masing-masing. Kegagalan ini umumnya disebabkan oleh faktor internal di partai itu sendiri karena adanya beragam jenis dan pola yang dikembangkan oleh para masing-masing kader. Akibatnya, pada pemilu-pemilu berikutnya partai lokal tersebut tak lagi hadir dalam dinamika politik nasional. Bahkan mekanisme kepartaian pun diperkecil kemudian hari seperti di masa Orde Baru.

Wacana partai politik lokal kembali muncul setelah reformasi dan pelaksanaan otonomi daerah yang menempatkan keragaman kondisi daerah turut diperhatikan dengan sungguhsungguh dalam pembangunan termasuk kehadiran partai politik lokal sebagai penyambung lidah masyarakat di tingkat lokal (Nugraha, 2012). Dalam kaitan dengan Aceh, Partai politik lokal di Aceh merupakan hasil kesepakatan MoU Helsinki antara Pemerintah Pusat dan Pimpinan GAM yang selanjutnya diatur melalui Undang-undang Pemerintah Aceh nomor 11 tahun 2006. Konflik yang berkepanjangan antara GAM dan Pemerintah RI menjadi alasan kuat hadirnya partai politik lokal dimana tujuan adalah memberikan kebebasan politik dalam demokrasi terutama untuk Eks Kombatan GAM dan masyarakat Aceh pada umunrnya. Selain itu, partai politik lokal juga sebagai alat dalam mejinakkan dan melunakkan kelompok separatisme di dalam demokrasi seperti kasus Aceh (Jafar, 2009).

Dalam UUPA Nomor 11 Tahun 2006 pada pasal 1 angka 14 partai politik lokal yaitu Partai politik lokal adalah organisasi politik yang dibentuk oleh sekelompok warga negara Indonesia 
yang berdomisili di Aceh secara suka rela atas dasar persamaan kehendak dan cita-cita untuk memperjuangkan kepentingan anggota, masyarakat, bangsa, dan negara melalui pemilihan anggota DPRA/DPRK, Gubernur/Wakil Gubernur, bupati/wakil bupati, dan walikota/wakil walikota. Dari definisi tersebut yang membedakan secara jelas bahwa partai politik lokal ialah partai politik yang bebasis lokal di suatu wilayah dalam hal ini Provinsi Aceh dengan tujuan khusus yakni meningkatkan partisipasi politik masyarakat di Aceh guna memperjuangkan cita-cita kehidupan bermasyarakat, penyelenggaraan pemerintahan daerah sesuai dengan kekhususan dan keistimewaan yang Aceh miliki.

Berdasarkan tafsiran hukum tersebut maka, partai - partai lokal yang secara aturan perundang-undangan (UU PA No. 11 Tahun 2006) sangat terbatas cakupan politiknya sehingga membutuhkan pendekatan politik ke partai-partai besar yang memiliki jaringan meluas secara nasional. Sehingga bagi para kader-kader partai lokal seperti hasil wawancara bersama informan maka bagi siapa saja yang yang ingin maju sebagai bakal caleg anggota DPR RI maka harus mendaftar ke partai nasional.

Kedudukan partai politik lokal di Indonesia menggambarkan sistem politik yang masih tertutup yang berbeda dari negara-negara seperti Inggris dan Spanyol yang memperbolehkan partai lokalnya ikut dalam pemilihan umum nasional. Kerajaan Inggris yang memiliki 4 negara bagian yaitu Inggris, Skotlandia, Wales, dan Irlandia Utara memiliki partai politik lokal di masing-masing negara-negara tersebut selain partai-partai nasional di Kerajaan Inggris. Di Skotlandia, partai politik yang terbesar merupakan partai politik lokal yang bernama Scottish National Party (SNP) dengan tujuan untuk memperjuangkan kemerdekaan yang sah dari Kerajaan Inggris. Wales dengan partai politik lokal bernama Plaid Cymru merupakan partai politik terbesar yang memiliki tujuan sama seperti partai politik lokal di Skotlandia yaitu memperjuangkan kemerdekaan dari Inggris. Di Irlandia Utara juga memiliki partai lokal terbesar bernama Democratic Unionist Party (DUP) tapi bukan untuk memperjuangkan kemerdekaan, tapi pemisahan dari Kerajaan Inggris Raya dan pembentukan satu Irlandia bersama Irlandia Selatan (Nugraha, 2012).

Spanyol memiliki dua partai politik lokal (regional parties) yaitu Convergence and Union dan Basque National Party yang memiliki tradisi lokal sangat kuat dengan perkembangan sejarah dan perbedaan bahasa yang mendominasi di wilayah Basque dan Catalonia. Meskipun partai lokal di Spanyol bukanlah partai besar karena politik Spanyol didominasi oleh dwi-partai namun dengan adanya partai lokal, penduduk disana dapat memperjuangkan kemerdekaan (Catalonia yang ingin memerdekaan diri dari Spanyol) melalui jalur-jalur demokaratis dan damai bukan kekerasaan atau perperangan.

Partai-partai lokal di negara-negara dengan sistem partai politik lokal yang terbuka seperti Inggris dan Spanyol memperbolehkan kedudukan partai politik lokal untuk ikut pemilihan umum secara nasional. Partai-partai politik di negaranegara tersebut memungkinkan partai lokal untuk menjadi partai nasional yang tidak mengenal perbedaan tingkat implementasi fungsi partai lokal dengan partai nasional. Bahkan negara-negara tersebut secara eksplisit memperbolehkan isu-isu kemerdekaan wilayah masuk kedalam agenda partai politik lokal. Selain itu, ada pula agenda-agenda lain untuk memperjuangkan hak-hak atas hidup dan otonomi.
Sullivan (2015) mengkategorikan tiga tujuan-tujuan keberadaan partai politik lokal yaitu Hak minoritas, partai politik lokal yang memperjuangkan dan melindungi serta memajukan hak warga negara terhadap ekonomi, sosial, budaya, dan bahasa seperti yang terjadi di Finlandia, partai politik lokal Svenska folkpartiet I Finland (SFP) - Swedish People's Party of Finland memperjuangkan etnis Swedia di Finlandia sebagai etnis minoritas. Kedua, partai politik lokal yang menginginkan otonomi daerah atau meningkatkan hak-hak ekonomi yang telah dimiliki oleh suatu daerah sebagai alasan umum keberadaan partai politik lokal dan ketiga, tujuan untuk mencapai kemerdekaan seperti kasus di Spanyol. Kerajaan Inggris (Skotlandia dan Wales), atau the parti Quebecois yang memiliki agenda memerdekaan wilayah Qubec dari Kesatuan Kanda (Nugraha, 2012).

Dalam kasus Aceh, partai politik bertujuan untuk otonomi yang luas terhadap hak-hak penguasaan ekonomi seperti yang tertuang dalam Pasal 160 ayat 1 UUPA tentang kewenangan Pemerintah Aceh untuk melakkan pengelolaan sumber daya migas bersama Pemerintah Pusat. Dalam sistem kepartaian di Indonesia pun, membangun partai politik lokal dengan tujuan memisahkan diri atau merdeka bertentangan dengan Pasal 9 dan Pasal 10 UU No2 Tahun 2008 yang menyatakan bahwa 1) Asas Partai Politik tidak boleh bertentangan dengan Pancasila dan Undang-Undang Dasar Negara Republik Indonesia dan Partai Politik harus bertujuan menjaga dan melindungi keutuhan NKRI. Dengan demikian maka keinginan bagi kader-kader PA yang ingin berkiprah ke level legislative nasional harus menggunakan partai politik nasional karena adanya keterbatasan pada UUPA dan kondisi politik Indonesia yang menerapkan sistem partai politik lokal tertutup.

\section{Afiliasi Partai Aceh dengan Partai Nasional}

Dari gambaran terhadap situasi dan dinamika partai politik lokal yang berkembang di Aceh maka partai politik lokal harus memiliki hubungan dengan partai nasional dengan tujuan untuk meningkatkan nilai tawar dan memperluas pengaruhnya sehingga persoalan yang ada di lokal (Aceh) akan menjadi pembahasan dan diskursus pada level nasional sehingga lokalitas masih tetap terjamin tanpa keluar dari bingkai nasional. Disinilah pertemuan 'kepentingan' dalam bentuk afiliasi antara partai lokal yang umumnya memiliki kedekatan basis yang lebih erat kepada masyarakat dan partai nasional yang membutuhkan penguatan institusi politik secara nasional (Nugraha, 2012) seperti yang dilakukan Partai Aceh dengan Partai Gerindra.

Secara aspek hukum yang telah diatur oleh UU No. 11 Tentang Pemerintahan Aceh pada pasal 80 ayat 1 bahwa partai politik lokal mempunyai hak yaitu melakukan afiliasi atau kerja sama dalam bentuk lain dengan sesama partai lokal atau partai politik nasional. Selanjutnya, UU ini juga merumuskan bahwa keanggotan partai politik lokal dapat merangkap keanggotan Partai Politik Nasional. Jadi tak mengherankan jika Ketua Umum Partai Aceh, Muzakkir Manaf (Mualem) juga menjabat Ketua Dewan Penasihat Partai Gerindra Provinsi Aceh sejak 2013 lalu. Serta kondisi saat ini saat Pemilu 2019 maka para kader partai lokal juga menjadi anggota di partai nasional.

Pola afiliasi partai politik lokal di Aceh dalam hal ini Partai Aceh dapat dibagi pada dua kategori yaitu official yaitu resmi dan non official yaitu tidak resmi. Afiliasi politik official yang dilakukan oleh Partai Aceh bersama dengan Partai Gerindra. 
Selanjutnyaafiliasi politik Partai Aceh dengan partai nasional seperti PAN, PSI, PBB, Partai NasDem, Partai Demokrat dengan menempatkan kader-kader partai lokal di berbagai parnas tersebut.

Afiliasi Partai Aceh dengan Partai Gerindra merujuk pada hasil wawancara dengan Muzakkir Manaf (Ketua Umum Partai Aceh) dan TA Khalid (Ketua DPD Gerindra Aceh) telah berlangsung setidaknya pada tahun 2013 dengan Muzakkir Manaf saat ditunjuk sebagai Ketua Dewan Penasehat Partai Gerindra Aceh. Dengan wewenang yang dimiliki oleh Mualem, maka afiliasi politik antara Partai Aceh dengan Gerindra berjalan di eksekutif dan legislatif. Pada afiliasi politik di eksekutif maka afiliasi politik diantara dua partai ini setidaknya dapat digambarkan saat Pemilukada Aceh tahun 2017 dimana Muzakkir Manaf dan TA Khalid berpasangan untuk maju sebagai Gubernur - Wakil Gubernur Aceh. Selanjutnya afiliasi ini pun berlanjut saat Pemilu Serentak 2019 dengan Mualem ditunjuk sebagai Ketua Tim Pemenangan Prabowo - Sandi Provinsi Aceh. Selain itu, dalam susunan legislatif di Partai Gerindra Aceh untuk bakal calon legisliatf DPR RI maka sepenuhnya keputusan dan kewenangan berada pada Muzakkir Manaf. Dengan rangkap jabatan yang dimiliki Muzakkir Manaf saat ini yang merupakan Panglima GAM maka memudahkan proses afilasi di internal Gerindra Aceh sehingga agenda-agenda politik dikedua belah pihak apakah itu agenda Partai Aceh/Partai Gerindra, atau kepentingan pribadi ataupun Aceh.

Disisi lain, Partai Aceh juga membangun afiliasi non official bersama partai-partai lain menjelang Pemilu 2019. Dengan menempatkan kader-kader partai lokal di berbagai partai nasional, maju beberapa kader partai lokal seperti di Partai Demokrat, PAN, PBB dan beberapa partai lainnya mayoritas karena motif atau kalkulasi politik secara pribadi (bukan perintah partai) disertai dengan dukungan 'rahasia' Sekretaris Partai Aceh, Komaruddin Abu Bakar yang mendukung Partai NasDem maka berbagai kepentingan-kepentingan yang ingin di delivery dapat dengan mudah tercapai.

Selain afiliasi politik, dinamika politik yang terjadi di intenal Partai Aceh menjelang 2019 cukup menarik jika ditinjau lebih lanjut pada fenomena party switchingdan motivasi beberapa kader partai lokal tersebut. Ketertarikan para kader partai lokal untuk berafiliasi kepada partai tertentu seperti apa yang dikatakan oleh Huwirtz (1984) melibatkan aspek psikologi sosial seperti kognitif (keyakinan), afektif (evaluasi), perilaku dan perangkat motivasi psikologis seperti opini evaluative terhadap penilaian pada partai dengan perasaannya, perilaku terntentu yang mengekspresikan sikap partisannya, dan keselarasan sikap partisan dengan sikap individu pada hal-hal lainnya (Hakim, M.A, 2014). Namun catatan penting lainnya ialah, party switching yang terjadi pada kader-kader partai lokal karena adanya aturan hukum yang membatasi bagi kader partai lokal untuk menjadi bacaleg DPR RI. Sehingga sebuah keniscayaan bagi mereka untuk bergabung dengan partai nasional secara bebas tanpa perlu mengundurkan diri dari keanggotan Partai Aceh dengan catatan penting bagi kader-kader partai lokal teyang ingin menjadi bacaleg DPR RI harus harus terlebih dahulu mengantongi izin tertulis dari pimpinan partai yang diatur sesuai dengan Peraturan Pemerintah Nomor 20 Tahun 2007 pada pasal 11 ayat (3) meskipun masih diperdebatkan yang merujuk pada aturan PKPU Nomor 20 Tahun 2018.

Afiliasi offensive yang dilakukan oleh Partai Aceh khususnya para elite bertujuan untuk memperjuangkan kepentingan yang ada pada tataran masyarakat daerah. Dengan pola afiliasi secara official antara Partai Aceh melalui Muzakkir Manaf dengan Partai Gerindra oleh TA Khalid mengarah pada apa yang disebut sebagai stratarchicform yakni dorongan kebutuhan untuk meningkatkan efektivitas partai guna merepesentasi ide-ide dan strukturisasi pilihan-pilihan bagi pemilih (Nugraha, 2012). Dengan kekuatan yang dimiliki masing-masing partai maka diharapkan tak hanya posisi legislative tapi juga eksekutif dapat direbut dan dipertahankan oleh kedua partai ini.

Namun bagi sebagian kalangan, afiliasi ini ternyata tak serta merta memberikan keuntungan yang seimbang bagi kedua partai. Bahkan, menurut beberapa pengamat, akademisi dan kader di Partai Aceh, afiliasi ini merugikan Partai Aceh kedepan. Beberapa hal yang mengakibatkan afiliasi ini tak berjalan dengan tujuan semestinya seperti, pemahaman dan kedewasaan politik yang masih minim di internal partai khususnya di masa grassroot, tingkat kualitas kader partai yang terpilih diiringin dengan kepercayaan masyarakat yang menurun terhadap petahana, tidak ada arah dan strategi yang jelas di internal Partai Aceh dalam menghadapi dinamika politik kedepan termasuk dalam menyikapi peta politik Pilpres 2019 dan Pileg. Oleh karenanya, untuk menyelamatkan kapal besar Partai Aceh yang notebene merupakan partai politik lokal dan marwah bagi masyarakat Aceh sudah semestinya melakukan evalusasi dan restrukturisasi kader-kadernya, merubah pola kerja dan citra menjadi partai terbuka dengan membuka ruang seluas-luasnya bagi elemen sipil lainnya untuk bergabung, menemukan kembali garis dan isu perjuangan, dan membangun komunikasi yang harmonisdi internal elit Partai Aceh untuk membawa kepada tujuan besar yaitu memperjuangkan kepentingan-kepentingan Aceh sebagai daerah istimewa dan Darussalam.

\section{SIMPULAN}

Partai Aceh yang merupakan partai lokal yang secara historis dibentuk oleh pimpinan eks kombatan GAM terus berupaya secara konsisten memperjuangkan kepentintan Aceh terutama dalam persoalan otonomi khusus, pengesahan bendara Aceh, serta butir - butir dari perjanjian Mou Helsinki dan implentasi dari UU Pemerintahan Aceh No. 11 Tahun 2006. Dalam aturannya UU Pemerintah Aceh 11/2006 bahwa Partai politik lokal adalah organisasi politik yang hanya dapat ikut berpartisipasi melalui pemilihan anggota DPRA/DPRK, Gubernur/Wakil Gubernur, bupati/wakil bupati, dan walikota/wakil walikota. Berdasarkan aturan yang berlaku tersebut yang menjelaskan bahwa sistem partai politik tertutup di Indonesia maka para kader Partai Aceh yang berkeinginan untuk 'menaikkan level' politik mereka di Senayan maka sebuah keniscayaan harus bergabung dengan partai-partai nasional seperti Partai NasDem, PSI, Partai Demokrat, PAN, dan lain sebagainya.

Partai Aceh sebagai partai lokal yang paling konsisten sebagai partai pemenang Pemilu di Aceh sejak tahun 2009 terus berupaya mempertahankan perolehan kursi dan memperluas kepentingan partai khususnya di level nasional yakni dengan menempatkan kader -kadernya di partai nasional. Namun dinamika yang terjadi selama proses Pemilu 2019, PA seakan tak mampu melakukan langkah - langkah strategis sehingga kondisi ini tak layak disebut sebagai afiliasi politik seutuhnya karena bergabungnya kader PA ke berbagai parnas adalah bentuk motif politik secara pribadi yang didasarkan pada kalkulasi politik 


\section{REFERENSI}

Creswell, J. (2012). Research Design Qualitative, Quantitative, dan Mixed Approaches. California.

Moleong, LJ. (2010). Metodologi Penelitian Kualitatif. Bandung: Remaja Rosda Karya.

Hendrik, Doni. (2010). Variabel-Variabel Yang Mempengaruhi Rendahnya Partisipasi Masyarakat Dalam Pilkada Walikota dan Wakil Walikota Padang Tahun 2008. Jurnal Demokrasi Vol. X No. 2. Hal 137-148.

Jafar, AW, M. (2009). Perkembangan Dan Prospek Partai Politik Lokal Di Propinsi Nanggroe Aceh Darussalam. Tesis: Universitas Diponegoro.

Ningsih, Novita Gustian. (2018). Afiliasi Politik Suku Jawa Dalam Pilkada Nagan Raya 2017 Studi Kasus Di Desa Kuala Trang. Skripsi. Universitas Islam Negeri Ar Raniry : Banda Aceh.

Nugraha, Dwi Puta. (2012). Partai Politik Lokal di Indonesia (Analisis Kedudukan dan Fungsi Partai Politik Lokal 1955 - 2011). Tesis. Universitas Indonesia.

Radean, Marius. (2013). Party Politics and Legislative Party Switching. Disertasi. Florida State University

Undang-Undang Nomor 11 Tahun 2006 tentang Pemerintahan Aceh

Keputusan Komisi Independen Pemilihan Pemilihan Aceh, Nomor 8 Tahun 2011

Peraturan Pemerintah Nomor 20 Tahun 2007 Tentang Partai Politik Lokal

Undang-Undang Nomor 2 Tahun 2011 Tentang Partai Politik

http://aceh.tribunnews.com/2019/05/07/kemenangan-dankekalahan-pa

https://news.detik.com/berita/901271/13-partai-politik-lokal-diaceh-mulai-diverifikasi, di akses tanggal 08 Januari 2019).

https://kumparan.com/acehkini/senjakala-partai-aceh-

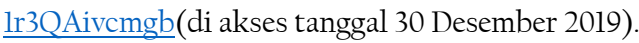

